\title{
The Innovation and Thinking on Postgraduates' Ideological and Political Education in a New Period
}

\author{
Tianhao Liu \\ Graduate School, Jilin Normal University, Siping, Jilin, 136000, China \\ email: liulaoshi66888@163.com
}

Keywords: Postgraduates; Ideological and Political Education; Innovation

\begin{abstract}
The ideological and political education is an important part of postgraduate education. Currently, in the face of new conditions, new changes and new problems appeared in graduates' ideological and political education, constantly to innovate new ways and new methods for graduates' ideological and political education, is very important for how to do well the job of postgraduates' ideological and political education and achieving the goal of cultivating high-quality innovative talents.

Strengthen the ideological and political education of postgraduates is of great importance to promoting the postgraduates' all-round development and cultivating qualified innovative talents. The mainstream of postgraduates' ideological and political situation is positive, healthy and upward, but there are also some new changes, new conditions and new problems. These new problems have brought new challenges to the job of postgraduates' ideological and political education. Therefore, constantly innovate the method of postgraduate's ideological and political education is the extremely urgent task of ideological and political education work.
\end{abstract}

\section{THE STATUS ANALYSIS OF PRESENT POSTGRADUATES’ THINKING}

\section{A. The Diversification of Thought Characteristics}

The postgraduates' thought characteristics are distinct different from undergraduates'. They have clear goals of life, strong analytical abilities and discriminabilities, intense patriotic emotion and active spirit of innovation, they are mature and stable in thought. However, with the rapid development of degrees and postgraduate education, the composition of postgraduate students' source is becoming more and more diversified. As a result, it leads to the difference in personal experience, age structure, educational level, knowledge structure, the political quality, and learning motivation among postgraduates. A part of students are not active in thought, their political belief is confusing, their ideal and faith are obscure and they are indifferent to political life; They tend to make problems idealized, superficial, and simplified when thinking of them; Their world outlooks are unstable and extreme. The new features of diversity on postgraduate students in thought will surely bring new challenges to postgraduates' ideological and political education.

\section{B. The Indifference to Collective Spirit}

The postgraduates are distinct different from undergraduates in life experience, personal appeal and learning style. Most graduate students are relatively more mature in thoughts. They possess the original insights and analysis abilities in understanding, and are unwilling to accept the ideological education instilled by the outside world indiscriminately. From the education experience, as graduate students, they have the experience of undergraduates' school life for four years, most of the students have formed a relatively stable world outlook, and some graduate students are already achieved financially independence, so they have strong independence compared with undergraduates[1]. At the same time, the learning styles of graduate students are relatively dispersed, it appears to be self-centered and lack of social responsibility in learning.

\section{Utilitarianism on Value Orientation}

Contemporary graduate students live in the era of social transformation, planned economy shifts to market-driven economy, and the world integration process is accelerating, so that the social trends of thought and cultural consciousness have an impact on the formation of graduates' value. Among them, the negative values such as money worship, hedonism, individualism and pragmatism influenced widely. Coupled with the severe employment situation, more and more graduate students 
only care about economic policies, employment and "tangible" benefits, while pay less attention to the national affairs, and collective consciousness is weak, and certain postgraduate students expect quick results and don't set down to researches, which can only be counterproductive finally.

\section{Complicated Mental Characteristics}

As there are differences in the group of postgraduates' on age characteristics, traits of character, professional qualities, learning goals, and also the objective reality problems on scientific research task, survival pressure and the job intention, these make the psychological state of the current group of postgraduate student have the trend of development to diversification and complication. With the enlargement of postgraduate enrollment scale, and the increasing number of graduate students, as well as the reasons of the inadequate reflection from the postgraduate students in learning, scientific research, employment, innovation and development, these all affect the postgraduate students' psychological health. At the same time, as postgraduates grow older, some of them are in the stage of raising families, get married and have their own children, support the elderly and educate their children, these problems and the contradictions of the postgraduate students' existing in economic conditions, working conditions, family conditions and expectations from both their parents and themselves, are all affect the graduate students’ psychological pressure.

\section{INNOVATE THE METHODS ON IDEOLOGICAL AND POLITICAL EDUCATION OF POSTGRADUATE STUDENTS}

\section{A. Adhere to the Combination of the Principle of People-oriented with the Education Concept of Serving for Students' Development}

The diverse characteristics of graduate students, request us adhere to the principle of people-oriented in postgraduates' ideological and political education. The $17^{\text {th }}$ Party Congress pointed out that "people-oriented" is the core of the scientific outlook on development clearly, which pointed out the direction on how to do well in graduates' ideological and political work under the new historical conditions of building a well-off society in an all-round way and building a harmonious socialist society, as well as putting forward new standards and requirements. Faced with new forms, new characteristics, new requirements and new challenges, graduates' ideological and political education work must be adhered to the "people-oriented" concept.[2] Adhering to the people-oriented, is to make students' developmental needs as a starting point, respecting students, protecting them and safeguarding their legitimate rights and interests; to vary from person to person on the basis of students' reality, teaching them in accordance of their aptitudes; To fully embody the service and care, and combine the care with respect and education management, making students grow happily and healthily; to cultivate the good psychological quality of graduates by shaping their sound personality; in the meantime, to guide the pursuit of political life and innovative spirit to the aspect of improving social development and individual comprehensive ability.

\section{B. Adhere to the Combination of Ideological and Political Education with Professional Education}

During the process of ideological and political education of postgraduates, not only the effect of the main channel of classroom teaching should be expressed, but also the graduates' main body consciousness should be strengthened. At present, in the process of graduates' cultivation, it is a common phenomenon that each university still pays more attention in professions than ideological and political education. Compared with undergraduates, the graduates' thought characteristics and the knowledge of ideological and political theory they mastered are more stable and solid, while traditional classroom teaching contents and methods have little effects on graduates' ideological and political education; therefore, to establish the system of combining closely ideological education and professional education is an important mechanism to ensure graduates' ideological and political education couldn't be marginalized; it is the necessary request to improve the quality of graduates' thought; it is also an important way of training talents of excellent morals and academic skills for society[3]

\section{Combined Ideological and Political Education with Practical Education}

Graduates' ideological and political education should combine the education of ideological and political theory with social practical education. When facing the new situations of graduates' ideological and political education, social practical education should be particularly strengthened. 
Graduate students are relatively more mature and stable in thoughts than undergraduates, ideological and political education out of reality can only disgust them. Graduates' ideological and political theory teaching should be less flubdub, polite formula, but more practice such as seminars and hot issues analysis that students are willing to accept. On the other hand, we should manage to combine the problems of solving thoughts with the problems of solving practice.

\section{Combination of Ideological and Political Education Work with Postgraduate Students' Management Work}

Compared with undergraduate students, graduate students' ideological and political education exist specificities. The graduates have the advantages of high cultural quality, ideological stability, but also there are some problems, such as loose behaviors, strong self-consciousness and the weak collective consciousness and the concept of organization, those bring challenges to the postgraduate students' management work. Not a radius of no rules, the perfect management system is the guarantees of do postgraduates' ideological and political education work well, therefore, the postgraduate students' ideological and political education should be combined with the postgraduate students' daily management, but also highlighting the importance of management. In terms of ideology, due to the educational objects are complicated, so we must adhere to people-oriented, respect the subjectivity of people, attach the great importance to the regularity of education, pay attention to the principle of separate treatment on generality and particularity, vary from person to person according to their aptitudes, and give full play to students' individuality and creativity, and then reach the goal of the unity of education and management.

\section{THE WAYS TO BROADEN THE GRADUATE STUDENTS' IDEOLOGICAL AND POLITICAL EDUCATION}

\section{A. Strengthen the Constructions of Campus Culture and Graduate Student Party and League Organizations}

A school is the major place to educate postgraduates' ideology and political thoughts, good school spirit and profound study style will make postgraduate students feel edificatory or infected unconsciously, it also can prompt the whole campus keep the aggressive mental states and good mental outlook, which is the necessary circumstance condition in the education of graduate students' ideology and political thoughts [4]. The penetration of the campus culture in education can not be replaced by class teaching or book knowledge, so we must rely on the Graduate Student Party or League, with academic activities and sports activities as its main form and carrier, actively carry out a variety of campus culture activities to build a harmonious campus culture atmosphere.

\section{B. Strengthen the Construction of Ideological and Political Work Teams}

Colleges and universities should focus on the construction of schools, faculties and full-time or part-time graduate students' ideological and political education work teams. According to a certain percentage, to distribute the whole staff to do the job for postgraduates' ideological and political education, these people should make clearly responsibility and strengthen, as well as standardize for postgraduates' ideological and political education and its management. Counselors, play a very important role in managing postgraduates, to the job of who are responsible for managing postgraduates' ideological and political education, there are dedicated teachers. In the daily life, counselors should not only convey many kinds of school policies, but also create opportunities for postgraduates to contact with their mentors, in this way to make postgraduates' mentors involved in the activities of their graduates' daily ideological and political education. Therefore, strengthen the work of postgraduates' ideological and political education needs establish a high-quality graduate counselors' team.

\section{Exert the Mentors'Action}

The former State Education Commission and the Propaganda Department of CCCPC pointed out in the Several Opinions on Strengthening the Postgraduates' Ideological and Political Work, “The mentors play an important role during the work of training the postgraduate students. We should improve the mentors' sense of responsibility for postgraduate students, and give full play to their enthusiasm for teaching. The mentors should not only to direct postgraduate students to study the theories, but also pay attention to the healthy growth of the political thoughts for postgraduate students, if they do so, they will achieve the goals of the real teaching and be a worthy example of a 
good teacher [5]". In the process of training the postgraduate students, the mentors are the people who have the most frequently contact with postgraduate students, and the love between them is the deepest. What on their shoulders are two tasks: the instructions for postgraduate students to research their papers and the postgraduates' ideological and political education. The education from the mentors reflects on the every link of the direction and training for the students. The mentors use their own actions to teach every student. The mentors should play their special part in the process of training postgraduate students.

\section{Pay Attention to the Psychological Education for Postgraduate Students}

As the number of graduate students has increased in recent years, the pressures of the postgraduate students come from learning, employment, family, emotion and other aspects are increasing, but the psychological tolerance is gradually reducing. The issues, paying more attention to the postgraduate students' psychological problems and strengthening the postgraduate students' psychologically healthy education, to promote and maintain the postgraduate's mental health, cultivating their good moral characters, and forming their perfect personalities, have become the important tasks for colleges. As the educators and managers of postgraduate students', we should understand and take good care of the students on our own initiative, and help postgraduate students solve the practical difficulties as far as possible, we should acquire how to enlighten people with the power of knowledge, to infect people with the emotional strength, and to inspire people with the charm of personality.

\section{E. Set up Network Communication Platform}

In recent years, make use of the network actively to carry out the postgraduate students' ideological and political education has become a new method for strengthening postgraduate students' ideological and political education. In order to better communicate with students and promote the mutual understanding, the managers of the postgraduate students' education should actively build and expand the platform of network ideological and political education. In order to promote the communication with the postgraduate students, we can build some platforms such as Fetion, QQ Groups and Renren to communicate with students. These platforms can not only reduce the distance between teachers and students, but also help the teachers understand the student's thought tendency in time, help students solve difficulties and problems they meet with.

The ideological and political education of the postgraduate students is a systematic project and a set of scientific theory system; it is also the key to cultivate the growth of the postgraduate students. In the management of the practical education, it is very important to know how to grasp the rules and characters of contemporary postgraduate students' ideological changes, and whether to do the work of postgraduate students' ideological and political well or not in the new way or new method of continuous innovation and application to the postgraduate students' ideological and political education.

\section{References}

[1] Shen Nan. A brief study on innovation of postgraduates' ideological and political education [J]. Education Arcade,2009 (4) 57.

[2] Fan De-quaCn. Discussion on contemporary graduate students ideological education mode [J] China's Collective Economy, 2010 (1) 176.

[3] Cao En-feng and so on. The problem faced by graduate students' ideological and political education and countermeasures [J]. Journal of Zunyi Normal College, 2009 (8) 108.

[4] Cao En-feng and so on. The problem faced by graduate students' ideological and political education and countermeasures [J]. Journal of Zunyi Normal College, 2009 (8) 109.

[5] Cao En-feng and so on. The problem faced by graduate students' ideological and political education and countermeasures [J]. Journal of Zunyi Normal College, 2009 (8) 109. 